\begin{tabular}{|c|c|c|c|c|}
\hline $\begin{array}{c}\text { Jurnal Penelitian \& } \\
\text { PPM }\end{array}$ & ISSN: 2442-448X & Vol 4, No: 2 & Hal: $129-389$ & Juli 2017 \\
\hline
\end{tabular}

\title{
FAKTOR YANG MEMPENGARUHI REMAJA DALAM MELAKUKAN BULLYING
}

\author{
OLEH: \\ ELA ZAIN ZAKIYAH ${ }^{1}$, SAHADI HUMAEDI ${ }^{2}$, MEILANNY BUDIARTI SANTOSO ${ }^{3}$ \\ 1. Mahasiswa Program Studi IImu Kesejahteraan Sosial FISIP Universitas Padjadjaran \\ 2. Departemen Kesejahteraan Sosial FISIP Universitas Padjadjaran \\ 3. Departemen Kesejahteraan Sosial FISIP Universitas Padjadjaran \\ E-mail: \\ (elazainnnnn@gmail.com; sahadi.humaedi@unpad.ac.id; meilannybudiarti13@gmail.com )
}

\begin{abstract}
ABSTRAK
Bullying adalah tindakan penggunaan kekuasaan untuk menyakiti seseorang atau sekelompok orang baik secara verbal, fisik, maupun psikologis sehingga korban merasa tertekan, trauma, dan tak berdaya (Sejiwa, 2008). Remaja yang menjadi korban bullying lebih berisiko mengalami berbagai masalah kesehatan, baik secara fisik maupun mental. Adapun masalah yang lebih mungkin diderita anak-anak yang menjadi korban bullying, antara lain munculnya berbagai masalah mental seperti depresi, kegelisahan dan masalah tidur yang mungkin akan terbawa hingga dewasa, keluhan kesehatan fisik, seperti sakit kepala, sakit perut dan ketegangan otot, rasa tidak aman saat berada di lingkungan sekolah, dan penurunan semangat belajar dan prestasi akademis. Dalam kasus yang cukup langka, anak-anak korban bullying mungkin akan menunjukkan sifat kekerasan. Seperti yang dialami seorang remaja 15 tahun di Denpasar, Bali, yang tega membunuh temannya sendiri karena dendamnya kepada korban. Pelaku mengaku kerap menjadi target bullying korban sejak kelas satu SMP.
\end{abstract}

Artikel ini bertujuan untuk mengetahui faktor-faktor penyebab terjadinya bullying oleh remaja, peran-peran dalam tindakan bullying, dan jenis-jenis bullying. Sumber data tulisan ini dilakukan dengan metode studi dokumentasi. Dalam artikel ini didapatkan hasil bahwa faktor-faktor yang mempengaruhi terjadinya bullying bisa datang dari individu, keluarga, kelompok bermain, hingga lingkungan komunitas pelaku. Tindakan ini sangat berhubungan dengan dunia pekerjaan sosial, yang dalam kasus ini dituntut untuk menjadi konselor bagi pelaku bullying.

Kata kunci: bullying, korban, bully, intimidasi.

\begin{abstract}
Bullying is an act of using power to bring any harm into a person or some people who is either verbally, physically, and psychologically victimized, traumatized, and helpless (Sejiwa, 2008). Teens who are intended to be the victims of bullying are at greater risk of health problems, both physically and mentally. As for problems more likely to be suffered by the victims of intimidation, include various mental problems such as depression, anxiety and sleep problems that may be carried into adulthood, physical health pathologies, such as headaches, abdominal pain and muscle load, and decreasing spirit of learning and academic achievement. In certain cases, victims of bullying may show violent characteristics. As happened to a 15 years old teenager in Denpasar, Bali, who killed his own friend for a revenge to the victim. Perpetrators claim to often be the target of bullying since the first grade of junior high school.
\end{abstract}


This article is intended to find out the causes of bullying by teenagers, roles in bullying, and types of bullying. The data source of this paper is done by documentation study method. In this article the results of factors that affect the occurrence of bullying come from individuals, families, play groups, to the community of perpetrators. This action is closely related to the world of social work, which they should be activate their role as a conselor for cutting the bully behavior off.

Key words: bullying, victims, bully, intimidation.

\section{Pendahuluan}

Kehidupan sosial manusia terdiri atas beberapa fase dan tingkatan. Pada saat lahir, manusia sebagai individu tumbuh dan berkembang di lingkungan keluarga. Setiap hari, ia melakukan kontak dan interaksi dengan keluarga terutama orang tua. Pada fase ini, bayi ditanamkan nilai-nilai yang dianut oleh orang tuanya.

Bertumbuh dewasa dan menjadi remaja, manusia sebagai individu mulai mengenal lingkungan yang lebih luas daripada keluarga. Sosialisasi yang dialami individu mulai bertambah luas. Individu mulai berinteraksi dengan teman sebayanya. Hal ini membuat keterampilan sosial individu makin meningkat. Jika nilai-nilai yang ditanamkan oleh kedua orang tuanya diserap dengan baik, maka keterampilan sosial yang dimiliki oleh individu tersebut bisa menjadi lebih baik. Hal itu disebabkan karena manusia tumbuh dan berkembang dari fase ke fase tanpa meninggalkan apa yang telah ia pelajari dari fase sebelumnya. Sebaliknya, apabila sosialisasi nilainilai yang ditanamkan keluarga kurang terserap oleh anak, maka bisa jadi perkembangan perilaku dan psikososialnya terhambat. Akibatnya, remaja mulai menunjukkan gejala-gejala patologis seperti kenakalan dan perilaku-perilaku beresiko lainnya, salah satunya adalah bullying.

Saat ini, bullying merupakan istilah yang sudah tidak asing di telinga masyarakat Indonesia. Bullying adalah tindakan penggunaan kekuasaan untuk menyakiti seseorang atau sekelompok orang baik secara verbal, fisik, maupun psikologis sehingga korban merasa tertekan, trauma, dan tak berdaya (Sejiwa, 2008). Pelaku bullying sering disebut dengan istilah bully. Seorang bully tidak mengenal gender maupun usia. Bahkan, bullying sudah sering terjadi di sekolah dan dilakukan oleh para remaja.

Dampak yang diakibatkan oleh tindakan ini pun sangat luas cakupannya. Remaja yang menjadi korban bullying lebihberisiko mengalami berbagai masalah kesehatan, baik secara fisik maupun mental. Adapun masalah yang lebih mungkin diderita anak-anak yang menjadi korban bullying, antara lain munculnya berbagai masalah mental seperti depresi, kegelisahan dan masalah tidur yang mungkin akan terbawa hingga dewasa, keluhan kesehatan fisik, seperti sakit kepala, sakit perut dan ketegangan otot, rasa tidak aman saat berada di lingkungan sekolah, dan penurunan semangat belajar dan prestasi akademis.

Contoh kasus terjadi pada seorang siswa sekolah dasar di Ohio yang tewas gantung diri menggunakan dasi karena dibully oleh teman sekolahnya. Bocah berumur 8 tahun ini menjadi korban bullying secara fisik. Ia kerap dipukuli oleh teman-temannya di sekolah. Contoh lain datang dari Texas. Seorang remaja perempuan nekat menembakkan pistol ke dadanya sendiri hingga tewas karena ia merasa dihujat habis-habisan di dunia maya.

Dalam kasus yang cukup langka, anak-anak korban bullying mungkin akan menunjukkan sifat kekerasan. Seperti yang dialami seorang remaja 15 tahun di Denpasar, Bali, yang tega membunuh temannya sendiri karena dendamnya kepada korban. Pelaku mengaku kerap menjadi target bullying korban sejak kelas satu SMP. Akibat perbuatannya, pelaku yang masih di bawah umur ini dijerat dengan Pasal 80 ayat 3 Undang-undang Nomor 35 tahun 2014 tentang Perlindungan Anak, serta KUHP Pasal 340, 338, dan 351.

Kasus ini membawa kepada penjelasan bahwa masyarakat khusunya harus lebih paham mengenai bullying. Apa yang menyebabkan remaja melakukan bullying, apa dampak bagi pelaku, korban, dan saksi, bagaimana bentuk-bentuk tindakan bullying, dan bagaimana cara mencegah dan memberhentikan tindakan penindasan ini.

\section{A. Pengertian Bullying}

Kata bullying berasal dari Bahasa Inggris, yaitu dari kata bull yang berarti banteng yang senang merunduk kesana kemari. Dalam Bahasa Indonesia, secara etimologi kata bully berarti penggertak, orang yang mengganggu orang lemah. Sedangkan secara terminology menurut Definisi bullying menurut Ken Rigby dalam Astuti (2008 ; 3, dalam Ariesto, 2009) adalah "sebuah hasrat untuk menyakiti. Hasrat 


\begin{tabular}{|c|c|c|c|c|}
\hline $\begin{array}{c}\text { Jurnal Penelitian \& } \\
\text { PPM }\end{array}$ & ISSN: 2442-448X & Vol 4, No: 2 & Hal: $129-389$ & Juli 2017 \\
\hline
\end{tabular}

ini diperlihatkan ke dalam aksi, menyebabkan seseorang menderita. Aksi ini dilakukan secara langsung oleh seseorang atau sekelompok yang lebih kuat, tidak bertanggung jawab, biasanya berulang, dan dilakukan dengan perasaan senang".

Bullying adalah bentuk-bentuk perilaku kekerasan dimana terjadi pemaksaan secara psikologis ataupun fisik terhadap seseorang atau sekelompok orang yang lebih "lemah" oleh seseorang atau sekelompok orang. Pelaku bullying yang biasa disebut bully bisa seseorang, bisa juga sekelompok orang, dan ia atau mereka mempersepsikan dirinya memiliki power (kekuasaan) untuk melakukan apa saja terhadap korbannya. Korban juga mempersepsikan dirinya sebagai pihak yang lemah, tidak berdaya dan selalu merasa terancan oleh bully. (Jurnal Pengalaman Intervensi Dari Beberapa Kasus Bullying, Djuwita, 2005 ; 8, dalam Ariesto 2009).

\section{B. Peran dalam Bullying}

Adapun pihak-pihak yang terlibat dalam perilaku bullying dapat dibagi menjadi 4 (empat) (dalam http://repository.usu.ac.id) yaitu:

a. Bullies (pelaku bullying) yaitu murid yang secara fisik dan/atau emosional melukai murid lain secara berulang-ulang (Olweus, dalam Moutappa dkk, 2004). Remaja yang diidentifikasi sebagai pelaku bullying sering memperlihatkan fungsi psikososial yang lebih buruk daripada korban bullying dan murid yang tidak terlibat dalam perilaku bullying (Haynie, dkk., dalam Totura, 2003). Pelaku bullying juga cenderung memperlihatkan simptom depresi yang lebih tinggi daripada murid yang tidak terlibat dalam perilaku bullying dan simptom depresi yang lebih rendah daripada victim atau korban (Haynie, dkk., dalam Totura, 2003). Olweus (dalam Moutappa, 2004) mengemukakan bahwa pelaku bullying cenderung mendominasi orang lain dan memiliki kemampuan sosial dan pemahaman akan emosi orang lain yang sama (Sutton, Smith, \& Sweetenham, dalam Moutappa, 2004).

Menurut Stephenson dan Smith (dalam Sullivan, 2000), tipe pelaku bullying antara lain:
(1) tipe percaya diri, secara fisik kuat, menikmati agresifitas, merasa aman dan biasanya populer,

(2) tipe pencemas, secara akademik lemah, lemah dalam berkonsentrasi, kurang populer dan kurang merasa aman, dan

(3) pada situasi tertentu pelaku bullying bisa menjadi korban bullying.

Selain itu, para pakar banyak menarik kesimpulan bahwa karakteristik pelaku bullying biasanya adalah agresif, memiliki konsep positif tentang kekerasan, impulsif, dan memiliki kesulitan dalam berempati (Fonzi \& Olweus dalam Sullivan, 2000).

Menurut Astuti (2008) pelaku bullying biasanya agresif baik secara verbal maupun fisikal, ingin popular, sering membuat onar, mencari-cari kesalahan orang lain, pendendam, iri hati, hidup berkelompok dan menguasai kehidupan sosial di sekolahnya. Selain itu pelaku bullying juga menempatkan diri di tempat tertentu di sekolah atau di sekitarnya, merupakan tokoh popular di sekolahnya, gerak geriknya sering kali dapat ditandai dengan sering berjalan di depan, sengaja menabrak, berkata kasar, dan menyepelekan/ melecehkan.

b. Victim (korban bullying) yaitu murid yang sering menjadi target dari perilaku agresif, tindakan yang menyakitkan dan hanya memperlihatkan sedikit pertahanan melawan penyerangnya (Olweus, dalam Moutappa dkk, 2004). Menurut Byrne dibandingkan dengan teman sebayanya yang tidak menjadi korban, korban bullying cenderung menarik diri, depresi, cemas dan takut akan situasi baru (dalam Haynie dkk, 2001). Murid yang menjadi korban bullying dilaporkan lebih menyendiri dan kurang bahagia di sekolah serta memiliki teman dekat yang lebih sedikit daripada murid lain (Boulton \& Underwood dkk, dalam Haynie dkk, 2001). Korban bullying juga dikarakteristikkan dengan perilaku hati-hati, sensitif, dan pendiam (Olweus, dalam Moutappa, 2004).

Coloroso (2007) menyatakan korban bullying biasanya merupakan anak 


\begin{tabular}{|c|c|c|c|c|}
\hline $\begin{array}{c}\text { Jurnal Penelitian \& } \\
\text { PPM }\end{array}$ & ISSN: 2442-448X & Vol 4, No: 2 & Hal: $129-389$ & Juli 2017 \\
\hline
\end{tabular}

baru di suatu lingkungan, anak termuda di sekolah, biasanya yang lebih kecil, tekadang ketakutan, mungkin tidak terlindung, anak yang pernah mengalami trauma atau pernah disakiti sebelumnya dan biasanya sangat peka, menghindari teman sebaya untuk menghindari kesakitan yang lebih parah, dan merasa sulit untuk meminta pertolongan. Selain itu juga anak penurut, anak yang merasa cemas, kurang percaya diri, mudah dipimpin dan anak yang melakukan hal-hal untuk menyenangkan atau meredam kemarahan orang lain, anak yang perilakunya dianggap mengganggu orang lain, anak yang tidak mau berkelahi, lebih suka menyelesaikan konflik tanpa kekerasan, anak yang pemalu, menyembunyikan perasaannya, pendiam atau tidak mau menarik perhatiaan orang lain, pengugup, dan peka.

Disamping itu juga merupakan anak yang miskin atau kaya, anak yang ras atau etnisnya dipandang inferior sehingga layak dihina, anak yang orientsinya gender atau seksualnya dipandang inferior, anak yang agamanya dipandang inferior, anak yang cerdas, berbakat, atau memiliki kelebihan. ia dijadikan sasaran karena ia unggul, anak yang merdeka, tidak mempedulikan status sosial, serta tidak berkompromi dengan norma-norma, anak yang siap mengekspresikan emosinya setiap waktu, anak yang gemuk atau kurus, pendek atau jangkung, anak yang memakai kawat gigi atau kacamata, anak yang berjerawat atau memiliki masalah kondisi kulit lainnya.

\section{Selanjutnya}

korbannya merupakan anak yang memiliki ciri fisik yang berbeda dengan mayoritas anak lainnya, dan anak dengan ketidakcakapan mental dan/atau fisik, anak yang memiliki ADHD (attention deficit hyperactive disorder) mungkin bertindak sebelum berpikir, tidak mempertimbangkan konsekuensi atas perilakunya sehingga disengaja atau tidak menggangu bully, anak yang berada di tempat yang keliru pada saat yang salah. ia diserang karena bully sedang ingin menyerang seseorang di tempat itu pada saat itu juga.

c. Bully-victim yaitu pihak yang terlibat dalam perilaku agresif, tetapi juga menjadi korban perilaku agresif (Andreou, dalam Moutappa dkk, 2004). Craig (dalam Haynie dkk, 2001) mengemukakan bully victim menunjukkan level agresivitas verbal dan fisik yang lebih tinggi dibandingkan dengan anak lain. Bully victim juga dilaporkan mengalami peningkatan simptom depresi, merasa sepi, dan cenderung merasa sedih dan moody daripada murid lain (Austin \& Joseph; Nansel dkk, dalam Totura, 2003). Schwartz (dalam Moutappa, 2004) menjelaskan bully-victim juga dikarakteristikkan dengan reaktivitas, regulasi emosi yang buruk, kesulitan dalam akademis dan penolakan dari teman sebaya serta kesulitan belajar (Kaukiainen, dkk., dalam Moutappa, 2004).

d. Neutral yaitu pihak yang tidak terlibat dalam perilaku agresif atau bullying.

\section{Faktor Penyebab terjadinya Bullying}

Menurut Ariesto (2009), faktor-faktor penyebab terjadinya bullying antara lain:

a. Keluarga.

Pelaku bullying seringkali berasal dari keluarga yang bermasalah : orang tua yang sering menghukum anaknya secara berlebihan, atau situasi rumah yang penuh stress, agresi, dan permusuhan. Anak akan mempelajari perilaku bullying ketika mengamati konflik-konflik yang terjadi pada orang tua mereka, dan kemudian menirunya terhadap teman-temannya. Jika tidak ada konsekuensi yang tegas dari lingkungan terhadap perilaku cobacobanya itu, ia akan belajar bahwa "mereka yang memiliki kekuatan diperbolehkan untuk berperilaku agresif, dan perilaku agresif itu dapat meningkatkan status dan kekuasaan seseorang". Dari sini anak mengembangkan perilaku bullying;

b. Sekolah

Pihak sekolah sering mengabaikan keberadaan bullying ini. Akibatnya, anakanak sebagai pelaku bullying akan mendapatkan penguatan terhadap perilaku mereka untuk melakukan intimidasi terhadap anak lain. Bullying berkembang dengan pesat dalam lingkungan sekolah sering memberikan 


\begin{tabular}{|c|c|c|c|c|}
\hline $\begin{array}{c}\text { Jurnal Penelitian \& } \\
\text { PPM }\end{array}$ & ISSN: 2442-448X & Vol 4, No: 2 & Hal: $129-389$ & Juli 2017 \\
\hline
\end{tabular}

masukan negatif pada siswanya, misalnya berupa hukuman yang tidak membangun sehingga tidak mengembangkan rasa menghargai dan menghormati antar sesama anggota sekolah;

c. Faktor Kelompok Sebaya.

Anak-anak ketika berinteraksi dalam sekolah dan dengan teman di sekitar rumah, kadang kala terdorong untuk melakukan bullying. Beberapa anak melakukan bullying dalam usaha untuk membuktikan bahwa mereka bisa masuk dalam kelompok tertentu, meskipun mereka sendiri merasa tidak nyaman dengan perilaku tersebut.

d. Kondisi lingkungan sosial

Kondisi lingkungan sosial dapat pula menjadi penyebab timbulnya perilaku bullying. Salah satu faktor lingkungan social yang menyebabkan tindakan bullying adalah kemiskinan. Mereka yang hidup dalam kemiskinan akan berbuat apa saja demi memenuhi kebutuhan hidupnya, sehingga tidak heran jika di lingkungan sekolah sering terjadi pemalakan antar siswanya.

e. Tayangan televisi dan media cetak

Televisi dan media cetak membentuk pola perilaku bullying dari segi tayangan yang mereka tampilkan. Survey yang dilakukan kompas (Saripah, 2006) memperlihatkan bahwa $56,9 \%$ anak meniru adegan-adegan film yang ditontonnya, umumnya mereka meniru geraknya (64\%) dan kata-katanya (43\%).

\section{Jenis Bullying}

Bullying juga terjadi dalam beberapa bentuk tindakan. Menurut Coloroso (2007), bullying dibagi menjadi tiga jenis, yaitu:

\section{a. Bullying Fisik}

Penindasan fisik merupakan jenis bullying yang paling tampak dan paling dapat diidentifikasi diantara bentuk-bentuk penindasan lainnya, namun kejadian penindasan fisik terhitung kurang dari sepertiga insiden penindasan yang dilaporkan oleh siswa.

Jenis penindasan secara fisik di antaranya adalah memukul, mencekik, menyikut, meninju, menendang, menggigit, memiting, mencakar, serta meludahi anak yang ditindas hingga ke posisi yang menyakitkan, serta merusak dan menghancurkan pakaian serta barangbarang milik anak yang tertindas. Semakin kuat dan semakin dewasa sang penindas, semakin berbahaya jenis serangan ini, bahkan walaupun tidak dimaksudkan untuk mencederai secara serius.

b. Bullying Verbal

Kekerasan verbal adalah bentuk penindasan yang paling umum digunakan, baik oleh anak perempuan maupun anak laki-laki. Kekerasan verbal mudah dilakukan dan dapat dibisikkan dihadapan orang dewasa serta teman sebaya, tanpa terdeteksi. Penindasan verbal dapat diteriakkan di taman bermain bercampur dengan hingar binger yang terdengar oleh pengawas, diabaikan karena hanya dianggap sebagai dialog yang bodoh dan tidak simpatik di antara teman sebaya.

Penindasan verbal dapat berupa julukan nama, celaan, fitnah, kritik kejam, penghinaan, dan pernyataan-pernyataan bernuansa ajakan seksual atau pelecehan seksual. Selain itu, penindasan verbal dapat berupa perampasan uang jajan atau barang-barang, telepon yang kasar, e-mail yang mengintimidasi, surat-surat kaleng yang berisi ancaman kekerasan, tuduhantuduhan yang tidak benar, kasak-kusuk yang keji, serta gosip.

\section{c. Bullying Relasional}

Jenis ini paling sulit dideteksi dari luar. Penindasan relasionaladalah pelemahan harga diri si korban penindasan secara sistematis melalui pengabaian, pengucilan, pengecualian, atau penghindaran. Penghindaran, suatu tindakan penyingkiran, adalah alat penindasan yang terkuat. Anak yang digunjingkan mungkin akan tidak mendengar gosip itu, namun tetap akan mengalami efeknya. Penindasan relasional dapat digunakan untuk mengasingkan atau menolak seorang teman atau secara sengaja ditujukan untuk merusak persahabatan. Perilaku ini dapat mencakup sikap-sikap tersembunyi seperti pandangan yang agresif, lirikan mata, helaan napas, bahu 


\begin{tabular}{|c|c|c|c|c|}
\hline $\begin{array}{c}\text { Jurnal Penelitian \& } \\
\text { PPM }\end{array}$ & ISSN: 2442-448X & Vol 4, No: 2 & Hal: $129-389$ & Juli 2017 \\
\hline
\end{tabular}

yang bergidik, cibiran, tawa mengejek, dan bahasa tubuh yang kasar.

\section{d. Cyber bullying}

Ini adalah bentuk bullying yang terbaru karena semakin berkembangnya teknologi, internet dan media sosial. Pada intinya adalah korban terus menerus mendapatkan pesan negative dari pelaku bullying baik dari sms, pesan di internet dan media sosial lainnya.

Bentuknya berupa:

1. Mengirim pesan yang menyakitkan atau menggunakan gambar

2. Meninggalkan pesan voicemail yang kejam

3. Menelepon terus menerus tanpa henti namun tidak mengatakan apa-apa (silent calls)

4. Membuat website yang memalukan bagi si korban

5. Si korban dihindarkan atau dijauhi dari chat room dan lainnya

6. "Happy slapping" - yaitu video yang berisi dimana si korban dipermalukan atau di-bully lalu disebarluaskan

Sedangkan Riauskina, dkk (2005, dalam Ariesto, 2009) mengelompokkan perilaku bullying ke dalam 5 kategori, yaitu:

a) Kontak fisik langsung (memukul, mendorong, menggigit, menjambak, menendang, mengunci, seseorang dalam ruangan, mencubit, mencakar, juga termasuk memeras dan merusak barang-barang yang dimiliki orang lain);

b) Kontak verbal langsung (mengancam, mempermalukan, merendahkan ( $p u t$ down), mengganggu, member panggilan nama (name-calling), sarkasme, mencela/mengejek, memaki, menyebarkan gosip);

c) Perilaku non verbal langsung (melihat dengan sinis, menjulurkan lidah, menampilkan ekspresi muka yang merendahkan, mengejek, atau mengancam, biasanya disertai oleh bullying fisik atau verbal) ; d) Perilaku non verbal tidak langsung (mendiamkan

seseorang, memanipulasi persahabatan sehingga retak, sengaja mengucilkan atau mengabaikan, mengirimkan surat kaleng);

e) Pelecehan seksual (kadang-kadang dikategorikan perilaku agresi fisik atau verbal).

E. Pelaku Bullying dalam Remaja

Menurut Carroll et al. (2009), terdapat empat faktor yang mempengaruhi remaja melakukan tindakan beresiko. Faktor tersebut adalah faktor individu, keluarga, peer group, dan faktor komunitas. Pelaku bullying, bila dikaitkan dengan teori tersebut, bisa dipengaruhi oleh lemahnya keterampilan sosial bully karena rasa simpati dan empati yang rendah dan memiliki tabiat yang menindas.

Keluarga juga dapat menjadi faktor seorang remaja menjadi bully. Misalnya, buruknya hubungan anak dengan orang tua. Remaja bisa jadi kehilangan perhatian di rumah sehingga dia mencari perhatian di sekolah dengan menunjukkan kekuasaannya terhadap seseorang yang dianggap lebih lemah dari pada dirinya. Selain itu, kekerasan yang dilakukan di rumah terhadap anak bisa jadi salah satu alasan mengapa seseorang menjadi bully. Pelaku bullying melakukan penindasan sebagai pelarian di lingkungan rumah yang selalu menindasnya dan membuat dia tidak berdaya.

Faktor lain yang merupakan faktor dominan yang merubah seseorang menjadi bully adalah kelompok bermain remaja. Faktor ini merupakan faktor yang muncul dan diadpsi ketika seorang individu tumbuh dan menjadi seorang remaja. Ketika remaja tidak memiliki pedoman dalam memilih kelompok bermain, remaja bisa jadi masuk ke dalam kelompokbermain yang mengarah pada kegiatan-kegiatan kenakalan remaja. Remaja merupakan individu dengan fase perkembangan psikologis di mana ia sangat membutuhkan pengakuan eksistensi diri. Kelompok bermain remaja yang menyimpang bisa jadi mencari pengakuan eksistensi diri dari menindas orang yang dirasa lebih lemah agar dia memiliki pengakuan dari lingkungannya bahwa ia memiliki keberanian dan kekuasaan.

Lingkungan komunitas juga bisa menjadi faktor pemicu seseorang melakukan bullying. 


\begin{tabular}{|c|c|c|c|c|}
\hline $\begin{array}{c}\text { Jurnal Penelitian \& } \\
\text { PPM }\end{array}$ & ISSN: 2442-448X & Vol 4, No: 2 & Hal: $129-389$ & Juli 2017 \\
\hline
\end{tabular}

Misalnya keberadaan suatu kelompok minoritas di dalam komunitasnya. Hal ini umumnya bisa memicu terjadinya bullying verbal berupa labelling pada suatu individu atau kelompokminoritas tertentu.

Berikut adalah hal-hal yang bisa dilakukan oleh kita sebagai pekerja sosial dengan remaja yang berperan sebagai konselor bagi remaja pelaku bullying (Lee, 2010).

- Bicaralah dengan bully dan cobalah cari tahu mengapa mereka merasa perlu berperilaku seperti itu. Cari tahu apa yang mengganggu mereka atau apa yang memicu tingkah laku tersebut

- Pastikan remaja bully mengerti bahwa perilaku merekalah yang tidak disukai, bukan mereka

- Yakinkan bully bahwa Anda bersedia membantu mereka dan Anda akan bekerja dengan mereka untuk menemukan cara untuk mengubah perilaku mereka yang tidak dapat diterima

- Bantu bully untuk menebus kesalahan pada korbannya. Jelaskan bagaimana cara meminta maaf karena telah membuat orang lain menderita dan bantu bully untuk menjelaskan alasan perbuatannya.

- Berikan bully banyak pujian serta dukungan dan pastikan Anda mengatakan pada bully ketika mereka berperilaku baik dan berhasil mengatur emosi dan perasaannya.

- Bersiap untuk mengkonfrontasi bully ketika mereka mulai membuat alasan atas perbuatannya seperti 'itu cuma bercanda' atau 'dia yang salah'. Jelaskan bahwa lelucon tidak menyebabkan kesulitan dan ancaman.

\section{DAFTAR PUSTAKA}

(n.d.). Retrieved Juni 12, 2017, from http://repository.usu.ac.id/bitstream/ha ndle/123456789/47777/Chapter\%20II.p df; jsessionid =35D4422C5DB57C049D80 F2372527001B?sequence $=4$

Ariesto, A. (2009). Pelaksanaan Program Antibullying Teacher Empowerment.
Retrieved Juni 12, 2017, from http://lib.ui.ac.id/file?file=digital/ 123656 -SK\%20006\%2009\%20Ari\%20p\%20-

\%20Pelaksanaan\%20programLiteratur.pdf

Carroll, A., Houghton, S., Durkin, K., \& Hattie, J. A. (2009). Adolescent Reputations and Risk. New York: Springer.

Coloroso, B. (2007). The Bully, The Bullied, and The Bystander. New York: HarperCollins.

Depresi Gara-gara Dibully, Remaja Ini Pilih Bunuh Diri. (2016, Desember 4). Retrieved Juni 12, 2017, from Tribun Jogja: http://jogja.tribunnews.com/2016/12/04 /depresi-gara-gara-dibully-remaja-inipilih-bunuh-diri

Lee, A. (2010). How to Grow Great Kids. Oxford: HowTo Content.

Raharjo, ST. 2015. Assessment untuk Praktik Pekerjaan Sosial dan Kesejahteraan Sosial. Bandung: Unpad Press 2015. Dasar Pengetahuan Pekerjaan Sosial. Bandung: Unpad Press. 2015. Keterampilan Pekerjaan Sosial: Dasar-dasar. Bandung, Unpad Press.

Sukiswanti, P. (2015, November 2). Remaja di Bali Nekat Bunuh Temannya karena Sering Dibully. Retrieved Juni 12, 2017, from sindonews.com: https://daerah.sindonews.com/read/105 8287/174/remaja-di-bali-nekat-bunuhtemannya-karena-sering-dibully1446470519

Surono, A. (2017, Mei 12). Tragis Murid SD Usia 8 Tahun Gantung Diri Pakai Dasi Gegara Di-bully Teman Sekolah. Retrieved Juni 12, 2017, from Tribun Medan: http://medan.tribunnews.com/2017/05/ 12/tragis-murid-sd-usia-8-tahungantung-diri-pakai-dasi-gegara-di-bullyteman-sekolah?page $=4$

TimSejiwa. (2008). Bullying: Panduan bagi Orang Tua dan Guru Mengatasi Kekerasan di Sekolah dan Lingkungan. Jakarta: Grasindo. 